\title{
A characteristics framework for Semantic Information Systems Standards
}

\author{
Boris Otto $\cdot$ Erwin Folmer • Verena Ebner
}

Received: 14 May 2011 / Revised: 7 September 2011/ Accepted: 2 November 2011/

Published online: 24 November 2011

(C) The Author(s) 2011. This article is published with open access at Springerlink.com

\begin{abstract}
Semantic Information Systems (IS) Standards play a critical role in the development of the networked economy. While their importance is undoubted by all stakeholders - such as businesses, policy makers, researchers, developers- the current state of research leaves a number of questions unaddressed. Terminological confusion exists around the notions of "business semantics", "business-to-business interoperability", and "interoperability standards" amongst others. And, moreover, a comprehensive understanding about the characteristics of Semantic IS Standards is missing. The paper addresses this gap in literature by developing a characteristics framework for Semantic IS Standards. Two case studies are used to check the applicability of the framework in a "real-life" context. The framework lays the foundation for future research in an important field of the IS discipline and supports practitioners in their efforts to analyze, compare, and evaluate Semantic IS Standards.
\end{abstract}

Keywords Semantic IS Standards - Standardization · Framework design · Case study research

B. Otto $(\bowtie) \cdot$ V. Ebner

Institute of Information Management, University of St. Gallen, Müller-Friedberg-Str. 8, 9000 St. Gallen, Switzerland

e-mail: boris.otto@unisg.ch

V. Ebner

e-mail: verena.ebner@unisg.ch

E. Folmer

TNO, Capitool 10, 7521 PL Enschede, The Netherlands

e-mail: erwin.folmer@tno.nl

E. Folmer

University of Twente, Drienerlolaan 5, 7522 NB Enschede, The Netherlands

e-mail: e.j.a.folmer@utwente.nl 


\section{Introduction}

\subsection{Motivation and problem statement}

The emergence of business networking over the last decades has posed new requirements on business interoperability (Österle et al. 1999). Business interoperability is the ability of an enterprise to cooperate with business partners and to efficiently establish, conduct and develop information technology (IT) supported business relationships with the objective to create value (Legner and Wende 2006). The notion of efficiency in this definition implies the use of information systems (IS) standards by the business partners. Alt and Fleisch (2000), for example, identify the need for semantic standardization of both business processes and data.

The issue of semantic IS standardization affects the needs of three different stakeholder groups. First, enterprises need semantic IS standardization as a prerequisite for business interoperability (Greiner et al. 2007; Legner and Lebreton 2007). When trying to select a Semantic IS Standard-see definition of the term below in Sect. 2-suitable for their needs, though, enterprises today are confronted with hundreds of them. So these enterprises must deal with a situation which Tanenbaum (1989) sarcastically described as follows: "The nice thing about standards is that you have so many to choose from." Enterprises have an interest in selecting the "right" Semantic IS Standard. They need to separate the "good" ones from the "bad" ones-in order to avoid "betting on a dead horse".

Second, policy makers and regulators want to provide a "fertile ground" for businesses, which also includes facilitating the standardization process and/or recommending certain standards. The European Union, for example, released several policy studies on standardization, and one of their policy goals is: "Increase the quality, coherence and consistency of ICT standards" (European Commission 2009). And in 2010 — right after her appointment as vice-president of the Digital Agenda for Europe-Mrs. Kroes (2010) made strong statements in favor of IS standardization and stipulated equal rights for industry and formal standards. The first key action in the digital agenda for Europe would be "to have more and better standards recognized and created in Europe". Also, Mrs. Kroes pointed out the particular importance of interoperability "boosting" competition, and that "we need more of that".

Third, IS research has an interest in semantic IS standardization, when, for example, advising policy makers on the issue, supporting the development of new Semantic IS Standards, and extending existing ones.

Various different terms closely related to semantic IS standardization are used in research and practice, ranging from "business semantics" (De Leenheer et al. 2010; Hofreiter et al. 2007), "business-to-business interoperability" (Lampathaki et al. 2009; Kajan and Stoimenov 2005), "interoperability standards" (Mykkanen and Tuomainen 2008), just to give a few examples. Furthermore, researchers and practitioners alike deplore the "semantic discourse on data and standards" (Lampathaki et al. 2009, p. 1046) and the "business standards dilemma" (Stuhec 2005).

Thus, the potential which is attributed to semantic IS standardization from various stakeholder groups in combination with the current terminological confusion indicates a need for action. 


\subsection{Research question and approach}

This paper introduces the notion of Semantic IS Standards to take up on the abovementioned need. It addresses the research question as to how Semantic IS Standards can be defined, in particular in the context of other IS standards, and what characteristics are needed to describe, analyze, compare and design them.

To adequately respond to this question, the paper proposes a characteristics framework for Semantic IS Standards. From an epistemological point of view, the framework forms an "analytical theory", i.e. one that "describes what is" (Gregor 2006). The framework is based on a deductive analysis of the state of the art in theory and practice and on multiple evaluation measures in the field. Among these evaluation measures are two case studies, one by the Dutch Ministry of Economic Affairs and one by Siemens Corporate Technology.

The paper contributes both to the scientific and to the practitioners' community. It advances the scientific body of knowledge because it sheds light on a research topic which so far has been defined and described only insufficiently. In doing so, the paper lays the foundation for future research aiming at using and validating the framework. Practitioners may benefit from the framework because they may use it as an instrument to facilitate internal and external communication and for describing and classifying their internal inventory of Semantic IS Standards.

The remainder of this paper begins with an overview of the theoretical foundations, followed by a description of the research process. The framework design is presented before being applied in a case study setting (Yin 2002). After that, the framework is evaluated against its design objectives. The paper discusses the research results with regard to their theoretical contribution and concludes with a brief summary and an outlook to future research.

\section{Related work}

\subsection{Basic concepts}

Terminological confusion exists both in the scientific and in the practitioners' community when it comes to semantic IS standardization. In fact, when discussing the topic with practitioners-in the context of the two case studies described below, for example-considerable uncertainty on the part of practitioners about the meaning of some fundamental concepts such as semantics, model, language, notation, specification, or standard became apparent.

The paper introduces the conceptual model in Fig. 1 as a response to this uncertainty and in order to lay a proper foundation for the future course of the work.

A real-world object is defined as a material or notional item existing in the real world. It can be seen from different point of views, depending on its contextdifferent business departments may have a different perception of the same realworld object, as they are using it in different contexts. In the pharmaceutical industry, for example, different notions of a product may exist in the same company. The research and development department may refer to the product mainly as a 


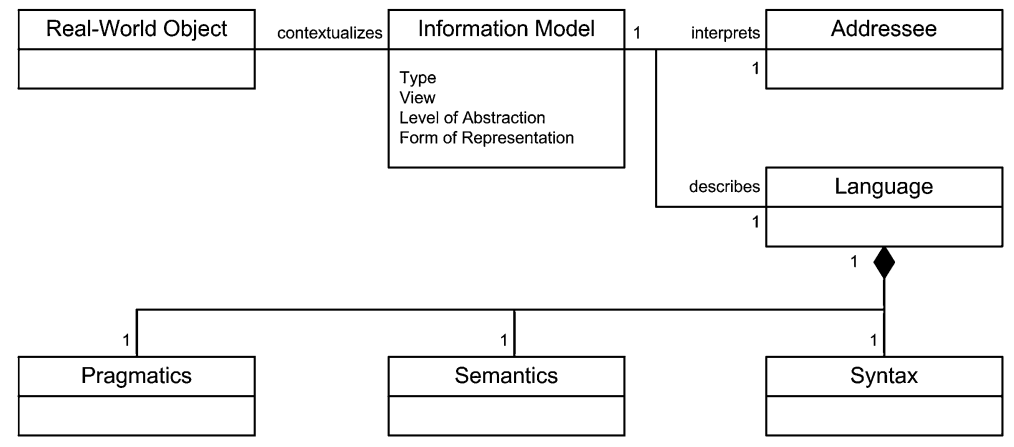

Fig. 1 Conceptual model

recipe or a chemical formula, while the logistics and distribution department may rather be interested in the width, height, and weight of the packaged product - and the sales department may be concerned about the product's registration in a market.

In general, a model is an "excerpt from reality". An information model describes a real-world object (Österle 1995; Lee 1999) in order to use the object within a given context and help achieve a common understanding of it. An information model can be defined as a business relevant illustration of reality (Hoberman et al. 2009).

Attributes of an information model are type, view, level of abstraction, and form of representation. The model type defines what kind of objects the model describes, and specifies what it is supposed to be used for. The attribute "Type" can have three instances, namely identification, classification, or description. An example of an information model addressing the identification of objects is the Global Trade Identification Number ${ }^{1}$ used to unambiguously identify products and stock keeping units. An example of a classification model is $\mathrm{eCl} @ \mathrm{ss}^{2},{ }^{2}$ a hierarchical model for grouping materials, products, and services. Description models, as the third type, are often further divided into models describing business processes (e.g. ebXML ${ }^{3}$ ) or messages (e.g. UN/EDIFACT ${ }^{4}$ ORDERS to describe purchase orders) (Vogel 2010).

The second attribute, i.e. the view of an information model, reduces the entirety of properties of real-world objects to those which are relevant when looking at the object from a certain perspective. Views help structure and simplify a model (Scheer 1992). The view of an information model can be instantiated in different ways. Business Engineering, for example, as a model oriented and method driven approach for transforming businesses, defines "Strategy", "Processes" and "Systems" as relevant views on an enterprise (Österle 1996; Österle and Blessing 2003). In contrast, the Architecture of Integrated Information Systems (Scheer 1992) defines the views "Function", "Organization", "Data", and "Control".

The view of a model must be separated from the third attribute, i.e. the level of abstraction. The Object Management Group (OMG) in its Model-Driven

\footnotetext{
1 See http://www.gs1.org/.

2 See http://www.eclass.de.

3 See http://www.ebxml.org/.

${ }^{4}$ See http://www.unece.org/trade/untdid/welcome.htm.
} 
Architecture (MDA) defines "computation-independent", "platform-independent", and "platform-dependent" as abstraction levels (OMG ORMS 2001). From a data modeling point of view, instantiations of the level of abstraction are "conceptual", "logical", and "physical" (Hoberman 2005; Jardine 1977). A conceptual model is typically directed at business users, since it clarifies the meaning of the most relevant objects, their attributes, and the relations of the business stakeholders given, such as department, organization, or industry (Hoberman et al. 2009). Logical and physical models allow the translation and implementation of concepts in a database management system (Brackett 1994).

The fourth model attribute is the form of representation. Typical instantiations are informal models (e.g. verbal descriptions), semi-formal models (e.g. EventDriven Process Chains), or formal models.

As an information model is intended to create understanding between two or more parties (Hoberman 2005; Lee 1999) which need to communicate with regard to the objects modeled, a common language needs to be defined. The communicating parties, called addressees in Fig. 1, are able to interpret the model by means of this common language.

In semiotics, which is the scientific study of signs and symbols, and in linguistics, which is the scientific study of human language, a language is defined through its constituents, namely pragmatics, semantics, and syntax (Brackett 1994; Hørlück 1996). Pragmatics describes the relation between the constructs of a language and their effect on the user. An example of pragmatics would be the effectiveness of mutually agreed contracts according to a civil law code. Semantics describes the relation of the signs of a model and the real-world object, i.e. the meaning of attributes and relationships of an object. And, finally, syntax defines the relations of signs in formal structures, i.e. the rules for composing and combining atomic data elements to larger entities.

Closely related to semantics of a language is the term "ontology". Based on Gruber's (1993) early work, Uschold and Gruninger (2004) define an ontology as a "formal, explicit specification of a shared conceptualization". An ontology defines all concepts and their relations within a certain "semantic domain" (Harel and Rumpe 2004). Thus, an ontology can be understood as the formal representation of the semantics of a language. Much overlap exists between the terms "ontology" and "semantic information model". In fact, ontologies are often used for "neutral authoring" of information objects or as neutral "interchange formats" (Uschold and Gruninger 2004).

Moreover, this paper acknowledges the distinction between "language" and "notation" in semiotics according to which a notation formalizes the language by signs and symbols and represents the "lexicalization" of a language (Müller 1982, p. 19). However, both terms are used interchangeably in this paper as all formal languages in IS are assumed to include a notation.

\subsection{Definitions}

A Semantic IS Standard is, first of all, a standard. One of the most frequently used definitions of the term "standard" is the one coined by ISO/IEC according to which 
a standard is a "document, established by consensus and approved by a recognized body, that provides, for common and repeated use, rules, guidelines or characteristics for activities or their results, aimed at the achievement of the optimum degree of order in a given context. Standards should be based on the consolidated results of science, technology and experience, and aimed at the promotion of optimum community benefits." (ISO/IEC 2004).

However, this definition is arguable since it is too focused on standards developed or ratified by formal standardization bodies such as ISO (Van Wessel 2008). It does not include informal standards, such as the Intermediate Document (IDoc) format introduced by SAP.

The IS community often distinguishes between electronic business standards and "traditional" IS standards (Zhao et al. 2007). This distinction was driven by the rise of the eXtensible Markup Language (XML) as a means to describe information models (see above). However, it is somewhat arbitrary, as differentiating between one purchase order encoded in XML and another purchase order encoded as ASCII text is not useful in practice.

Moreover, literature names specific IS standards, such as "business transaction standards" (Rukanova 2005) or Vertical Industry Standards (VIS) (Steinfield et al. 2007). While the former represent a certain information model type (see above), the latter are directed at a certain group of addressees, namely an industry sector.

Referencing the Open Systems Interconnection (OSI) model, Steinfield et al. (2007) refer to Semantic IS Standards as follows: "Standards at the presentation and application levels are [...] semantic standards, while standards below these levels are called syntactical standards. The internet protocol is an example of a syntactical communication network standard; and EDI standards are an example of semantic [IS] standards [...]. [Semantic IS Standards] can focus on a single industry sector or purport to be applicable across sectors." This understanding, though, does not include the definition of a standard and, through its industry notion, government oriented standards.

As a response to the current terminological confusion, this paper proposes the following definition: A Semantic IS Standard is an information model which is described by a language appropriate for the domain it is intended to be used in and the documentation of which is established by consensus of its addressees for common and repeated use. Being an information model, a Semantic IS Standard must specify the semantics of the objects which it contextualizes.

\subsection{Theories on standardization}

Many scientific contributions examine the theoretical foundations of the development, the adoption and selection of IS standards in general. To study the development of IS standards mainly theories from social sciences are used. Backhouse et al. (2006), for example, applied the circuit of power theory to explain the development of the BS7799 information security standard, and Nickerson and zur Muehlen (2006) take an organizational ecology perspective on the development of web services choreography standards. 
Research on the development of Semantic IS Standards is still limited. One of the few contributions available today is the study by Folmer et al. (2011) analyzing the quality of Semantic IS Standards including their development processes.

To explain the adoption of standards a large body of knowledge exists-mainly using network economics and diffusion of innovation theory. The theory of network economics assumes that the value of a good increases with its use. The theory is, thus, well suited to explain the adoption of standards (Economides 1996; David and Greenstein 1990). Much research is available for example, regarding the lock-in effect and path dependency of standards adoption. Stango (2004) also addresses the "winner-takes-it-all" effect in standardization.

Many contributions exist addressing the adoption of Semantic IS Standards. The literature comprises a number of adoption models (Chen 2003; Kelly et al. 2006; Mendoza and Ravichandran 2007) and case studies on individual Semantic IS Standards (Chang and Jarvenpaa 2005; Boh et al. 2007; Thomas et al. 2008), for example. Based on the RosettaNet case in particular, adoption strategies from the perspective of standards development organizations have been identified, which are market oriented (to raise awareness), technology oriented (to improve standard to lower implementation costs), policy oriented (to influence regulation), and relations oriented (to convince key players) (Boh et al. 2007). Both RosettaNet and MISMO case studies have granted insight in setting up development and adoption strategies for Semantic IS Standards (Markus et al. 2006).

The selection of a standard by an individual company is studied from a cost and benefit perspective. Weitzel et al. (2006), for example, address standardization costs and benefits within their integrated model of standard diffusion and Chen and Forman (2006) study whether vendors can influence switching costs.

Furthermore, Legner and Lebreton (2007) propose a comprehensive account of the body of knowledge related to Semantic IS Standards in the context of interoperability - as one of the main drivers of Semantic IS Standards adoption.

Despite the fact that Semantic IS Standards are IS standards, too, Zhao et al. (2005) has shown that it might be inappropriate to use results from general standardization research for Semantic IS Standards. Organizations developing Semantic IS Standards are facing different challenges than traditional standards development organizations including rapid technology development and divergent preferences of stakeholders.

\subsection{Frameworks for Semantic IS Standards}

A literature analysis with regard to existing frameworks for Semantic IS Standards led to four major contributions (see Appendix 1). Although the analysis revealed many similarities, the frameworks are in fact quite different. Compared to the others, the framework by Lampathaki et al. (2009) is rather limited, addressing XML based standards only. The framework proposed by Nelson et al. (2005) focuses on standards development organizations. The frameworks proposed by Mykkanen and Tuomainen (2008) and by Pawlowski and Kozlov (2010) are the most detailed approaches. In particular, the Reference Model Analysis Grid by Pawlowski and Kozlov is a methodology for assessing standards, with the broader 


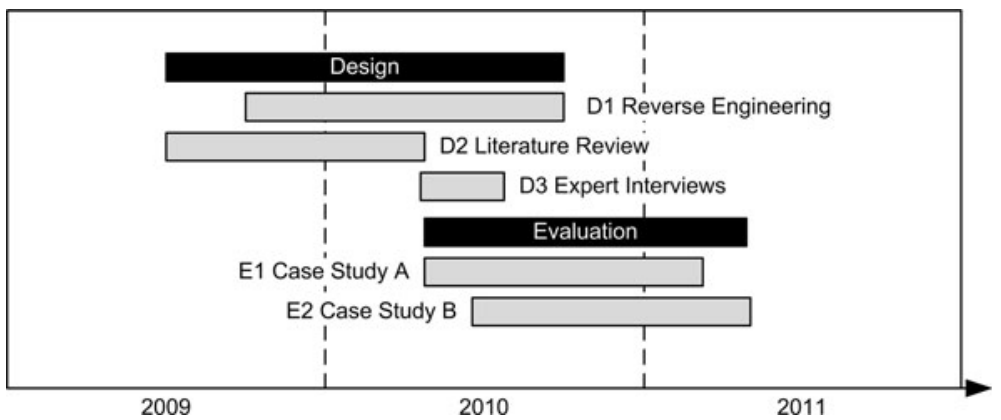

Fig. 2 Research process

aim to combine them in a harmonized framework. Besides the descriptive framework listed in Appendix 1, the authors propose an assessment framework with eight concepts (Pawlowski and Kozlov 2010):

- Transformation and analysis: How should the standard be used for transformation of the organization (i.e. of its systems and processes)?

- Maintenance: How is the standard maintained?

- Effectiveness and efficiency: How does the standard lead to effectiveness and efficiency?

- Flexibility and integration: How flexible can the standard be integrated within an organization?

- Coordination and knowledge management: How are coordination mechanisms and knowledge exchange supported by the standard?

- Interoperability: How does the standard lead to interoperability?

- Understandability and usability: How understandable and usable is the standard?

- Coherence: How coherent is the standard with other standards?

Little research has been done so far on actually comparing different Semantic IS Standards. One of the few contributions is proposed by Kabak and Dogac (2010) who analyzed a number of Semantic IS Standards, among which are UN/EDIFACT, UBL 2.0, ${ }^{5}$ and OAGIS BOD 9.0. ${ }^{6}$

Overall, existing literature comprises valuable work regarding Semantic IS Standards. A comprehensive framework, however, which supports the analysis and evaluation of Semantic IS Standards is missing as of today.

\section{Research process}

The work presented in this paper followed a two-step research process (see Fig. 2). Step 1 included the design of the characteristics framework for Semantic IS Standards and consisted of three activities. Activity D1 used a reverse engineering

\footnotetext{
5 See http://www.oasis-open.org/committees/tc_home.php?wg_abbrev=ubl.

${ }^{6}$ See http://www.oagi.org/oagis/9.0/.
} 
(Chikofsky and Cross 1990) approach to analyze existing Semantic IS Standards and to increase the understanding regarding their characteristics and constituents. The results were continuously combined with the results of a parallel literature review (Activity D2) regarding approaches for classification of Semantic IS Standards (see Appendix 1). Preliminary versions of the framework were reflected and discussed in multiple expert interviews (Activity D3). In general, expert interviews allow for explication of the knowledge of experts in the field (Meuser and Nagel 1994). Two expert interview streams were used:

- Four sessions comprising six experts from the Dutch research organization TNO, who have been involved in the development of Semantic IS Standards. These interviews were part of Case Study A (see below).

- One expert session comprising the members of the BOMOS working group of the Dutch government, which created the Development and Management model of Open Standards (NOiV 2011). The session included ten standards developers from different domains and was held in November 2010.

The result of Step 1 is the characteristics framework for Semantic IS Standards. Describing reality, the framework forms an analytical theory according to the topology of theories in IS proposed by Gregor (2006).

Step 2 of the research process aimed at validating the framework, i.e. in particular its applicability and usefulness in a "real-life" context. Case studies, in general, are well suited for this purpose, since they allow studying a contemporary phenomenon within its context (Benbasat and Zmud 1999; Yin 2002; Eisenhardt 1989). Case Study A involved the Dutch Ministry of Economic Affairs and was conducted between December 2010 and February 2011. From a research perspective, Case Study A pursued two goals. First, it aimed at providing practitioner feedback during the framework design phase (see above). Second, it was used to check the practical applicability of the framework. Case Study B was conducted in a collaborative research project with Siemens Corporate Technology and was conducted between August 2010 and January 2011. It aimed at demonstrating the applicability of the framework in a private business environment. Both cases studies were of participatory nature (Baskerville 1997). The researchers took over an active role by moderating and facilitating the progress of the projects. However, they did not influence the decision of the practitioners with regard to analysis and evaluation of Semantic IS Standards. Appendices 3 and 4 provide details on the two cases.

\section{Framework design}

\subsection{Design objectives}

Gregor (2006) has stipulated a number of requirements an analytical theory needs to meet in order to contribute to the scientific body of knowledge. Among these requirements are usefulness, appropriateness, clarity, and completeness. 
The usefulness of the theory materializes in the use cases in which it is supposed to offer support. Regarding the characteristics framework for Semantic IS Standards, three major use cases were identified:

- Analysis and comparison of Semantic IS Standards: Both researchers and practitioners as well as standardization bodies must be able to analyze and compare existing Semantic IS Standards in order to determine overlaps and "white spots".

- Evaluation and selection of Semantic IS Standards: Organizations which are in the process of evaluating and selecting Semantic IS Standards must be able to base their assessment on a complete, comprehensive and unbiased foundation.

- Influence and further development of Semantic IS Standards: Assessments of the diffusion and acceptance of certain Semantic IS Standards as well as their quality must be based on a solid terminological foundation.

The appropriateness of a framework is what Becker et al. (1995) in their "Guidelines for orderly Modelling" (GOM) call "systematic structure". One example to support a systematic structure would be to introduce different views. Apart from appropriateness, the requirement of clarity can also be found in the GOM. Becker et al. (1995) have stipulated that the information model must be understandable by its addressees. Finally, the completeness of a framework ensures-according to Gregor (2006) — that no important concepts are omitted. The GOM see completeness constrained by the economic viability of the application of a framework and by the focus on relevant concepts only.

Economic viability also requires that the framework must be adaptable with regard to the use case, because each case might require a different level of detail and only a subset of the concepts covered by the framework.

\subsection{Framework overview}

The characteristics framework for Semantic IS Standards consists of three levels, of which the first two levels comprise categories and sub-categories, while the third level represents concepts. The concepts represent characteristics of Semantic IS Standards and can be assigned with values. Therefore, description, analysis, and comparison by means of the framework are carried out on the basis of values on the conceptual level. All concepts are assigned to exactly one sub-category, and every sub-category is assigned at least to one concept. Both the introduction of a hierarchical structure and the grouping of concepts into sub-categories and of sub-categories into categories aim at ensuring the framework's comprehensibility (see GOM above).

Figure 3 shows the categories and sub-categories of the characteristics framework for Semantic IS Standards. In total, 37 concepts are assigned to 10 subcategories, which themselves are assigned to the four level-one categories. The framework proposes the use of metadata, such as "Name", "URL" etc. This kind of information is supposed to be attributed directly to the root element, i.e. the Semantic IS Standard. It is not included in the framework itself, because it serves identification purposes rather than analysis and evaluation of different Semantic IS Standards. 


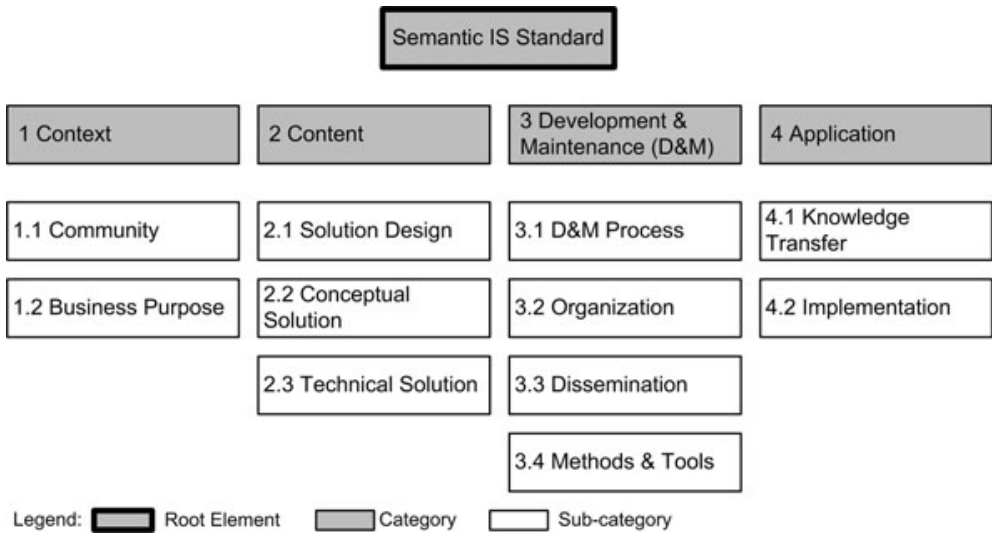

Fig. 3 Framework for Semantic IS Standards

Table 1 First-level categories

\begin{tabular}{lll}
\hline ID & Category & Description \\
\hline 1 & Context & Concepts related to the standard's environment \\
2 & Content & Concepts related to the solution offered by the standard \\
3 & Development and & Concepts related to the standardization activities and their \\
& maintenance & organization \\
4 & Application & Concepts related to implementation and use of the standard \\
\hline
\end{tabular}

The first level of the framework includes four categories, namely "Context", "Content", "Development and Management", and "Application" (Table 1).

The context (category 1) is the environment in which different stakeholders are facing a certain business problem for which a standard solution is required. The actual solution, i.e. the content of the standard, forms the second category (category 2) on the framework's first level. This is what many researchers and practitioners refer to a standard in the narrower sense of an information model (see above). Moreover, each standard must be developed and maintained (category 3). All concepts related to the use of the Semantic IS Standard are included in category 4.

\subsection{Framework in detail}

\subsubsection{Sub-categories and concepts of the category "Context"}

Table 2 shows the sub-categories and concepts related to the category "Context". The column on the right indicates how the sub-categories and concepts are supported by literature. ${ }^{7}$

\footnotetext{
7 The codes refer to the categories and concepts in Appendix 1. This approach recurs in all following three tables.
} 
Table 2 Sub-categories and concepts related to "Context"

\begin{tabular}{|c|c|c|c|}
\hline ID & $\begin{array}{l}\text { Sub-categories } \\
\text { and concepts }\end{array}$ & Description & $\begin{array}{l}\text { Literature } \\
\text { support }\end{array}$ \\
\hline 1.1 & Community & Stakeholders related to the standard & B.1. \\
\hline 1.1 .1 & $\begin{array}{l}\text { Target } \\
\text { community }\end{array}$ & The addressees the standard is intended for & $\begin{array}{l}\text { B.3. } \\
\text { C.1. }\end{array}$ \\
\hline 1.1 .2 & $\begin{array}{l}\text { Adopting } \\
\text { community }\end{array}$ & The community using the standard & D.6. \\
\hline 1.1 .3 & $\begin{array}{l}\text { Active } \\
\text { community }\end{array}$ & $\begin{array}{l}\text { Stakeholders actively participating in the design, maintenance, } \\
\text { dissemination etc. of the standard }\end{array}$ & \\
\hline 1.2 & Business purpose & The business purpose for which the standard is designed & B.2. \\
\hline 1.2 .1 & Business goals & $\begin{array}{l}\text { The real-life problem the standard aims at overcoming and } \\
\text { derived business goals }\end{array}$ & $\begin{array}{l}\text { C.2.a. } \\
\text { D.2. }\end{array}$ \\
\hline 1.2 .2 & $\begin{array}{l}\text { Application } \\
\text { domain }\end{array}$ & $\begin{array}{l}\text { Description of targeted domain of use, including rules and } \\
\text { constraints like laws and regulations }\end{array}$ & \\
\hline 1.2 .3 & Costs and benefits & $\begin{array}{l}\text { Benefits and costs related to achieving the business goals } \\
\text { through use of the standard }\end{array}$ & \\
\hline
\end{tabular}

While the "Community" is principally confirmed as a concept in literature on Semantic IS Standardization (Pawlowski and Kozlov 2010; Lampathaki et al. 2009), no further specification of the term is given. The expert interview sessions revealed the need for further distinction between target and adopting community. For example, the classification standard eCl@ss was initially designed to help match the needs of purchasing departments in large chemical companies, but has been adopted by many other sectors and functional departments eventually. The concept "Active community" was included as a result of the literature analysis on IS standardization in general. Nickerson and zur Muehlen (2006), for example, stress the importance of the active community during the development of a standard.

Including the "Business purpose" as a sub-category in the framework is backed by literature on Semantic IS Standardization (Lampathaki et al. 2009; Pawlowski and Kozlov 2010; Mykkanen and Tuomainen 2008). But again the discussion with subject matter experts resulted in the demand for a more detailed elaboration of this category.

\subsubsection{Sub-categories and concepts of the category "Content"}

Table 3 shows the sub-categories and concepts of the category "Content".

The category "Content" consists of three sub-categories, namely "Solution design", "Conceptual solution", and "Technical solution". While "Solution design" addresses underlying design principles and foundations (e.g. XML for many electronic business standards), "Conceptual solution" and "Technical solution" represent two different layers of abstraction. While the "Solution design" is relatively well supported by existing literature, hardly any contribution can be found in the scientific body of knowledge regarding the "Conceptual solution" and the "Technical solution". 
Table 3 Sub-categories and concepts related to "Content"

\begin{tabular}{|c|c|c|c|}
\hline ID & $\begin{array}{l}\text { Sub-categories } \\
\text { and concepts }\end{array}$ & Description & $\begin{array}{l}\text { Literature } \\
\text { support }\end{array}$ \\
\hline 2.1 & Solution design & Approaches and methods underlying the design of the standard & A.1. \\
\hline 2.1 .1 & Design paradigm & A high-level paradigm underlying the standard design & A.4. \\
\hline 2.1 .2 & $\begin{array}{l}\text { Methods and } \\
\text { languages }\end{array}$ & Methods and languages used in the design of the standard & $\begin{array}{l}\text { A.8. } \\
\text { B. } 4 \text {. }\end{array}$ \\
\hline 2.1 .3 & Architecture & $\begin{array}{l}\text { Architectural design choices for the standard, including } \\
\text { functional and technical architecture, and relationships with } \\
\text { other standards }\end{array}$ & $\begin{array}{l}\text { B.5. } \\
\text { B.6. } \\
\text { B.7. } \\
\text { B.8. } \\
\text { C.2.b. } \\
\text { C.4.a. } \\
\text { D.3. }\end{array}$ \\
\hline 2.2 & $\begin{array}{l}\text { Conceptual } \\
\text { solutions }\end{array}$ & $\begin{array}{l}\text { The design of the solution in concepts like descriptions and } \\
\text { models }\end{array}$ & $\begin{array}{l}\text { A.2. } \\
\text { A. } 3 \text {. }\end{array}$ \\
\hline 2.2 .1 & $\begin{array}{l}\text { Domain model } \\
\text { (requirements) }\end{array}$ & A description of the domain environment of the standard & \\
\hline 2.2 .2 & Constraints & $\begin{array}{l}\text { Constraints described as a solution, expressed like business } \\
\text { rules, related to the standard. Such rules can express data } \\
\text { dependencies based on the process status }\end{array}$ & \\
\hline 2.2 .3 & Process & $\begin{array}{l}\text { The design of the flow of activities encapsulated within the } \\
\text { standard. This might include process diagrams, actors } \\
\text { involved, timing, error handling, cancellation process, etc. }\end{array}$ & \\
\hline 2.2 .4 & Data, information & $\begin{array}{l}\text { The design of data and information objects encapsulated within } \\
\text { the standard. This might include messages/documents, } \\
\text { ontologies, code lists, taxonomies, data dictionaries, sharable } \\
\text { data components, etc. }\end{array}$ & \\
\hline 2.3 & $\begin{array}{l}\text { Technical } \\
\text { solutions }\end{array}$ & The design of the solution in technical artifacts & A.5. \\
\hline 2.3 .1 & Format & $\begin{array}{l}\text { The format of the technical solutions, in which the conceptual } \\
\text { solutions are represented }\end{array}$ & \\
\hline 2.3 .2 & $\begin{array}{l}\text { Medium } \\
\quad \text { (transport) }\end{array}$ & Solutions related to technical communication aspects & \\
\hline
\end{tabular}

\subsubsection{Sub-categories and concepts of the category "Development and Management"}

Many studies on standardization are focused on the development of standards (Folmer et al. 2010). This is closely related to the management of standards, involving standards development organizations. Table 4 contains the sub-categories and concepts of the category "Development and Maintenance".

In spite of the fact that many studies exist dealing with the concepts of the Category "Development and maintenance", the experts from the practitioners' community considered the level of detail to be insufficient. Lampathaki et al. (2009), for example, identify "openness" as a relevant concept, but do not elaborate it further. According to the expert feedback, more detailed information is needed in 
Table 4 Sub-categories and concepts related to "Development and maintenance"

\begin{tabular}{|c|c|c|c|}
\hline ID & $\begin{array}{l}\text { Sub-categories } \\
\text { and concepts }\end{array}$ & Description & $\begin{array}{l}\text { Literature } \\
\text { support }\end{array}$ \\
\hline
\end{tabular}

3.1 Development and Activities related to the development and maintenance of the

C.3. maintenance solutions the standard offers

D.4. process

\subsubsection{Initiation}

3.1.2 Design

3.1.3 Formalization

3.1.4 Review and testing

3.2 Organization

3.2.1 Quality management

3.2.2 Rights policy

3.2.3 Governance

3.2.4 Finance model

3.2.5 Vision, strategy

3.2.6 Operational model

3.3 Dissemination

3.3.1 Promotion, dissemination strategy

\subsubsection{Compliance strategy}

3.3.3 Communication strategy

3.4 Methods and tools

3.4.1 Methods and tools
The initiation process of exploring new maintenance requests or requirements related to the standard

The design process of creating solutions for requirements and maintenance requests

The transformation of the design of the solution in the requested formats, both conceptual and technical

The review of the formalized solution by the stakeholders. If possible, the solution may be tested in practice

Organization of the development and maintenance of the standard

Quality assurance and benchmarking of the standard

D.6.

D.11.

A.7.

B.1.

C.3.a.

C.4.b.

The description of the rights policy chosen for the standard

Governance model for the organization of the standard. Including decision-making, release policy, and complaints handling

C.5.

C.6.

D.4.

The model chosen for financing the costs of the development and management processes

The long-term vision for the standard, and its strategy for fulfilling the vision

The operational approach for the development and maintenance of the standard, including meetings policy (location, frequency, openness of meetings), versioning policy, backwards compatibility policy, documentation policy etc.

Activities related to disseminating the standard

A.7.

The strategy and its activities related to the promotion of the standard for achieving the desired adoption rate, including addressing the status of the standard by both the own organization and external organizations

The strategy to test and assure compliance of implementations to the standard by a certification program, for example

The overall strategy regarding communication with different stakeholders, using different communication channels.

Including the strategy related to publication of the documents in which the standard is described

Artifacts useful during implementation

D.8.

C.7.

D.7.

Methods and tools used for implementation of the standard (a validation service, for example)

practice about the development process, the governance structures of the standardization body, and about quality management aspects. This demand is supported by literature on IS standardization in general. Detailed "Development and 
maintenance" concepts are necessary as they represent what Grindley (1995) refers to as "standards reinforcement mechanisms" (p. 27). These mechanisms are decisive for widespread adoption of a standard. And a detailed representation of "Organization" concepts is required to be able to analyze behavioral aspects such as described by Backhouse et al. (2006) and Nickerson and zur Muehlen (2006), for example (see also Sect. 2.3).

Moreover, it turned out that openness is too broad a concept to be included as one characteristic. In fact, openness is multidimensional referring to open meetings, open intellectual property rights and open access to documents, for example (Krechmer 2009). Furthermore, openness it is not unambiguously evaluated. While a high level of openness might be desirable in one context, it might be considered disadvantageous in another (see e.g. Boh et al. 2007).

Apart from that, the sub-category "Methods and Tools" can hardly be found at all in existing literature. Only Lampathaki et al. (2009) briefly address this point under "Ease of use and implementation" (D.8.).

\subsubsection{Sub-categories and concepts of the category "Application"}

Finally, the application of the standard is an important category with regard to the use cases described above as it influences potential further adoption, for example. Table 5 shows the sub-categories and concepts of the category "Application".

Concepts of the category "Application" are addressed only to a limited extent in literature. Some contributions, though, supporting the sub-category "Knowledge Transfer" can be found. They remain, however, unspecific. And regarding the category "Implementation", only Pawlowski and Kozlov (2010) address the point when referring to "Usage and validation" (B.9.). The general relevance of "Reference Implementations" in IS standardization is supported by the prominent Amaya $^{8}$ case, for example.

\section{Framework application in case studies}

\subsection{Case A: Dutch ministry of economic affairs}

\subsubsection{Context}

The Dutch government is leading in Europe when it comes to defining public strategies for adopting and promoting open IS standards. The policy named "Netherland Open in Connection" (NOiV 2011) is characterized by a stringent definition of openness and a "Comply or Explain" regime for the public sector. The latter implies that open standards that have been selected by the standardization board after a stringent procedure must be used within the public sector. Several

\footnotetext{
${ }^{8}$ Amaya is a reference implementation for internet standards which is maintained by W3C (Quint 2010).
} 
Table 5 Sub-categories and concepts related to "Application"

\begin{tabular}{|c|c|c|c|}
\hline ID & $\begin{array}{l}\text { Sub-categories } \\
\text { and concepts }\end{array}$ & Description & $\begin{array}{l}\text { Literature } \\
\text { support }\end{array}$ \\
\hline 4.1 & $\begin{array}{l}\text { Knowledge } \\
\text { transfer }\end{array}$ & $\begin{array}{l}\text { Concepts related to the dissemination of knowledge about the } \\
\text { standard }\end{array}$ & $\begin{array}{l}\text { A. } 8 . \\
\text { B. } 10 .\end{array}$ \\
\hline 4.1.1 & Helpdesk & $\begin{array}{l}\text { Helpdesk availability to answer (implementation) questions } \\
\text { about the standard }\end{array}$ & B. 12. \\
\hline 4.1 .2 & $\begin{array}{l}\text { Events and } \\
\text { training }\end{array}$ & $\begin{array}{l}\text { Availability of events and a training program to share } \\
\text { knowledge about the standard }\end{array}$ & \\
\hline 4.1 .3 & Consultants & Availability of consultants/implementers for the standard & \\
\hline 4.1 .4 & Pilots (support) & $\begin{array}{l}\text { Documentations about pilot implementations and availability of } \\
\text { support for pilots }\end{array}$ & \\
\hline 4.1 .5 & $\begin{array}{l}\text { Representation } \\
\text { forms }\end{array}$ & $\begin{array}{l}\text { Knowledge about the standard is available in all kinds of } \\
\text { representation forms, like specifications, implementation } \\
\text { guidelines, examples, code lists, websites, flyers etc. }\end{array}$ & \\
\hline 4.2 & Implementation & Concepts supporting the implementation of the standard & B.9. \\
\hline 4.2 .1 & $\begin{array}{l}\text { Reference } \\
\text { implementation }\end{array}$ & $\begin{array}{l}\text { Documentation about reference implementation of the standard } \\
\text { which can be used as a template for further implementation }\end{array}$ & \\
\hline 4.2 .2 & $\begin{array}{l}\text { Certificated } \\
\text { implementations }\end{array}$ & $\begin{array}{l}\text { Information about implementations of the standard (potentially } \\
\text { certified by an appropriate authority such as the standards } \\
\text { development organization). Like reference implementations, } \\
\text { also certified implementations can be used as templates for } \\
\text { further adoption }\end{array}$ & \\
\hline
\end{tabular}

standards that are included in the "Comply or Explain" list are the result of publicprivate partnership efforts.

The Dutch Ministry of Economic Affairs wanted to know what other standards are available that have public-private partnership properties and that are aimed at solving economically and socially important goals. Standards identified should be allowed for future addition to the Comply or Explain list.

Three main criteria for the selection of Semantic IS Standards were defined:

- (1) Maturity of a standard: A standard may be adopted if there has been sufficient practical experience in using it.

- (2) Potential of a standard: A standard may be adopted if it has the potential to substantially contribute to the achievement of certain economic and/or social goals.

- (3) Maintenance and development of a standard: A standard may be adopted if the processes for maintaining and developing it are organized, open and structured.

The Ministry of Economic Affairs added an additional criterion for their specific purposes, namely (4) public-private partnership. The criterion implies that stakeholders from both the public and the private domain should have an interest in the standard. 


\subsubsection{Standards selection process}

The characteristics framework for Semantic IS Standards was used to support both the definition of the selection criteria and the process of selecting Semantic IS Standards relevant for the Comply or Explain list.

The definition of selection criteria consisted of five steps. Step 1 aimed at the identification of the needs with regard to the standards' selection (see above). Step 2 mainly included the formulation of questions the stakeholders wanted to have answered with regard to the standard. In Step 3 these questions were mapped to concepts in the framework. Step 4 looked for potential gaps, before Step 5 aimed at adjusting the questions so that they still would reflect the stakeholders' needs and in parallel match the concepts of the framework. Table 6 shows the mapping of framework concepts to the questions identified in Step2.

Several of the questions are related to metadata of Semantic IS Standards, namely name, website, abbreviation, or start date (attributed on "root" level, see above). The level of adoption can be determined by looking at the number of implementations in relation to the targeted audience. As this is, of course, not an easy task to

Table 6 Application of framework in Case A

\begin{tabular}{|c|c|c|c|}
\hline Item & Question addressed & $\begin{array}{l}\text { Needs } \\
\text { addressed }\end{array}$ & Framework concepts \\
\hline 1 & Name of the standard & General & $\begin{array}{l}\text { Semantic IS standard (root } \\
\text { element) }\end{array}$ \\
\hline 2 & Functional and organizational domain & General & $\begin{array}{l}\text { Target community (1.1.1), } \\
\text { application domain }(1.2 .2)\end{array}$ \\
\hline 3 & Website & General & $\begin{array}{l}\text { Semantic IS standard (root } \\
\text { element) }\end{array}$ \\
\hline 4 & $\begin{array}{l}\text { Usage on national, European, international } \\
\text { level }\end{array}$ & $\begin{array}{l}\text { General, } \\
\text { Maturity }\end{array}$ & $\begin{array}{l}\text { Adopting community (1.1.2), } \\
\text { implementation (4.2) }\end{array}$ \\
\hline 5 & Start date & Maturity & $\begin{array}{l}\text { Semantic IS standard (root } \\
\text { element) }\end{array}$ \\
\hline 6 & Important stakeholders & $\begin{array}{c}\text { Maturity, } \\
\text { Public- } \\
\text { private }\end{array}$ & Adopting community (1.1.2) \\
\hline 7 & Number of participants & Maturity & Active community (1.1.3) \\
\hline 8 & Level of adoption & $\begin{array}{l}\text { Maturity, } \\
\text { Potential }\end{array}$ & $\begin{array}{l}\text { Implementation (4.2), target } \\
\text { community (1.1.1) }\end{array}$ \\
\hline 9 & Contribution to economic and social goals & Potential & $\begin{array}{l}\text { Business goals (1.2.1), costs } \\
\text { and benefits }(1.2 .3)\end{array}$ \\
\hline 10 & $\begin{array}{l}\text { Contribution to reducing the administrative } \\
\text { burden or to improved inspection }\end{array}$ & Potential & $\begin{array}{l}\text { Business goals (1.2.1), costs } \\
\text { and benefits (1.2.3) }\end{array}$ \\
\hline 11 & Profit/non-profit orientation of organization & Organization & Finance model (3.2.4) \\
\hline 12 & Finance model & Organization & Finance model (3.2.4) \\
\hline 13 & Participation model & Organization & Operational model (3.2.6) \\
\hline 14 & Decision model/governance & Organization & Governance (3.2.3) \\
\hline 15 & Availability & Organization & Rights policy (3.2.2) \\
\hline
\end{tabular}


do, in Case A multiple sources of evidence were used (for example, not only the big players but also small and medium-sized companies).

The standard selection process started with the creation of a longlist of Semantic IS Standards based on desktop research and input from subject matter experts. Based on the assessment of experts ten standards were selected for further analysis. The analysis of the shortlisted standards was conducted using the characteristics framework for Semantic IS Standards.

One example of the application of the framework is included in Appendix 2 in order to give an idea as to what information was gathered from each standard by using these questions.

\subsubsection{Applicability of the framework}

Table 6 shows which parts of the framework were used. First, it shows that some metadata aspects are covered. Second, the biggest part deals with the context (the Organizational and the Problem domain) and with the implementation of the standard. This part is needed for gathering information regarding the maturity and the potential of the standard. The third part that is covered comprises aspects from the development and maintenance organization. The table also shows that in this application case no question relates to the "Content" category of the standards.

Apart from that, the framework helped identify gaps in the set of selection criteria:

- Content (Category 2): By not looking at the content it remains uncertain what the quality of the solution will be in relation to the problem.

- Knowledge Transfer (Sub-category 4.1): Knowledge transfer will have an impact on the ease and speed of adoption. By not looking at this aspect essential input for assessing the maturity and potential of the standard might be disregarded.

The Ministry of Economic Affairs was very much aware of the gaps. However, the gaps were not considered crucial. The focus of the project was not on contentrelated concepts such as the quality of Semantic IS Standards. Overall, the applicability of the framework for Case A was considered high by all project stakeholders.

\subsection{Case B: Siemens Corporate Technology}

\subsubsection{Context}

Siemens Corporate Technology is a corporate organization supporting the Siemens divisions with expert knowledge on recent research and technology developments in areas of importance for the company.

With regard to IS standardization, a variety of specifications and standards exists across the organization. Business and data objects, for example, typically have been defined on an individual basis for each organizational unit, business process, and application system. In order to increase transparency on business processes and 
reduce costs for data integration and transformation, Siemens Corporate Technology aimed at introducing a process oriented Enterprise Data Architecture with a common definition of business objects both from a functional and an IT view. The Enterprise Data Architecture was supposed to make use of existing business data standards as much as possible. A project was started aiming at identifying business data standards available on the "market" and evaluating them for the use at Siemens. Recommended standards were supposed to be used by Siemens business units in order to provide a common understanding of business objects.

\subsubsection{Standards evaluation process}

In the beginning of the project, Siemens Corporate Technology identified five criteria against which existing standards were to be evaluated:

- (1) Business focus: The standard should have a focus on the modeling of business objects from the business view.

- (2) Popularity/diffusion/reach: The standard should be widespread in the user community.

- (3) Topicality: The standard should be still in development and the latest version should be up-to-date (i.e. the latest update should not be older than 3 years).

- (4) Industry scope of Siemens: The standard should focus on one of the domains Siemens engages in (industry, energy, and healthcare).

- (5) Definition of a data model: The standard should support the modeling of business objects and their relationships.

A sixth criterion was (6) support of the standard by software tools available in the market. It turned out, however, that this criterion could not be assessed for all standards.

As a consequence of the overall goal to develop an Enterprise Data Architecture, Siemens Corporate Technology focused only on those Semantic IS Standards which included specifications of business objects and/or catalogue data. Other standards with a focus only on messages, item identification or classification, and business processes were disregarded.

As a first step in the evaluation process, an inventory of standards comprising about two hundred entries was created based on an extensive internet research. Included in the search were the following sources:

- Standardization organizations (e.g. ISO, UN/CEFACT);

- Research funding agencies (e.g. European Commission);

- Inter-trade organizations;

- Software vendors (e.g. IBM, SAP);

- Key market players (e.g. Chrysler, Toyota from the automotive industry).

In a second step, the inventory was narrowed down to a shortlist of about 40 standards using the criteria described above, except for the industry focus. A third step reduced the number of standards to twelve, which were then transferred to the so-called evaluation list. For this evaluation list the industry focus and the relevance for Siemens Corporate Technology were regarded as criteria. 
Table 7 shows the list of evaluation criteria and their mapping to the framework concepts.

One example of the standards evaluation process is included in Appendix 5 to illustrate what information was gathered from each standard by using these criteria.

On the basis of these criteria, an evaluation of the standards selected in the evaluation list was conducted (see Table 8). For this evaluation only the evaluation criteria 11-20 were relevant. A first value indicated the extent to which the criterion was met by a certain standard. The criteria allowed ranking Semantic IS Standards on an ordinal scale. For evaluation of the case of Siemens Corporate Technology the scale was chosen to range from 1 to 3 , with " 1 " meaning the criterion is not met at all, " 2 " meaning the criterion is met to a certain extent, and " 3 " meaning the criterion is fully met.

In addition to that, priorities were assigned by Siemens Corporate Technology, ordering the criteria according to the relevance of the organization. The priorities $0-3$ were chosen, with " 1 " representing lowest and " 3 " representing highest priority. The value " 0 " was introduced to exclude the criterion from the evaluation due to its irrelevance. The result values were computed by creating the average, weighted with the corresponding priority. The evaluation resulted in five Semantic IS Standards

Table 7 Application of framework in Case B

\begin{tabular}{|c|c|c|}
\hline Item & Evaluation criteria & Framework concepts \\
\hline 1 & Version & Semantic IS standard (root element) \\
\hline 2 & Description & Semantic IS standard (root element) \\
\hline 3 & Registered standard & Promotion, dissemination strategy (3.3.1) \\
\hline 4 & $\begin{array}{l}\text { Standardization } \\
\text { organization }\end{array}$ & All concepts in sub-category "Organization" (3.2) \\
\hline 5 & Industry & Application domain (1.2.2) \\
\hline 6 & Scope & Business goals (1.2.1), architecture (2.1.3) \\
\hline 7 & Developer & Active community (1.1.3) \\
\hline 8 & Origin, contributions & Active community (1.1.3) \\
\hline 9 & Link & Semantic IS standard (root element) \\
\hline 10 & Content & All concepts in category "Content" (2) \\
\hline 11 & Structural cardinality & Architecture (2.1.3) \\
\hline 12 & Semantic cardinality & Architecture (2.1.3) \\
\hline 13 & Representation & $\begin{array}{l}\text { Concepts in sub-categories "Conceptual solutions" (2.2) and } \\
\text { "Technical Solutions" (2.3) }\end{array}$ \\
\hline 14 & Predefined content & Data, information (2.2.4) \\
\hline 15 & Extensibility & Architecture (2.1.3) \\
\hline 16 & $\begin{array}{l}\text { Integration with other } \\
\text { models }\end{array}$ & Architecture (2.1.3) \\
\hline 17 & Industry acceptance & Adopting community (1.1.2) \\
\hline 18 & Tool support & Methods and tools (3.4) \\
\hline 19 & Openness & $\begin{array}{l}\text { Rights policy (3.2.2), governance (3.2.3), finance model (3.2.4), } \\
\text { operational model (3.2.6) }\end{array}$ \\
\hline 20 & Availability & Rights policy (3.2.2) \\
\hline
\end{tabular}




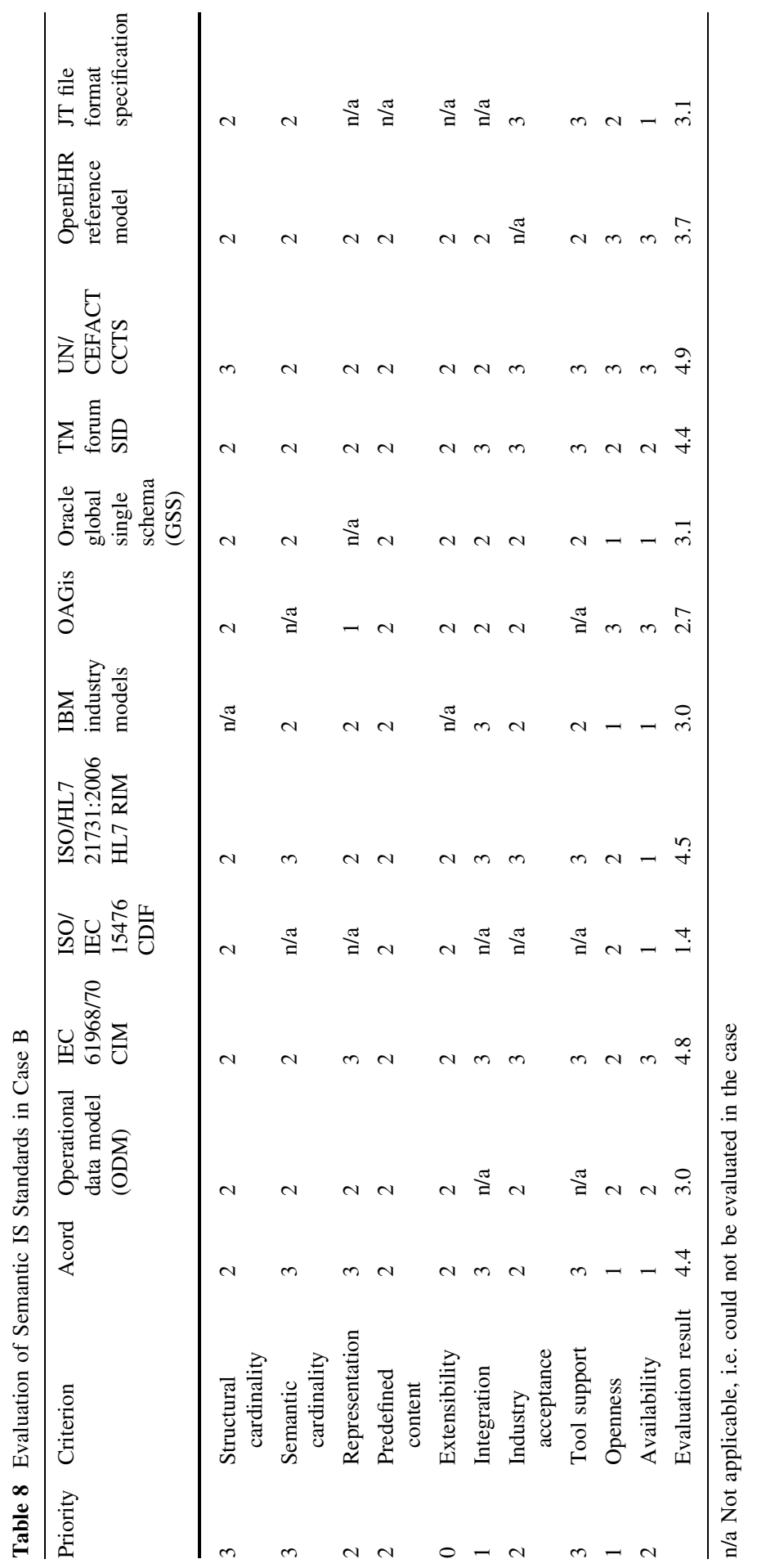


with a value higher than 4.0, what was considered a threshold for recommendation. These standards were Acord, ${ }^{9} \mathrm{CIM},{ }^{10} \mathrm{HL} 7 \mathrm{RIM},{ }^{11} \mathrm{SID},{ }^{12}$ and CCTS. ${ }^{13}$

\subsubsection{Framework applicability}

The characteristics framework for Semantic IS Standards in the case of Siemens Corporate Technology covered all required concepts. Most of the evaluation criteria referred to the categories Context and Content, followed by Development and Maintenance. For the Siemens case a general description of the standards was necessary, e.g. name, industry focus, developer, contributors, and a short description of the standard's content. This description was also used for the selection of the standards relevant for Siemens Corporate Technology. For further evaluation of the standards and for contrasting them, more details with regard to content were gathered. Here, also some aspects of the applicability were regarded.

\section{Evaluation}

Both Gregor (2006) in her contribution on theories in IS and the GOM introduced by Becker et al. (1995) stipulate a multidimensional evaluation approach for theoretical constructs such as taxonomies. In the following, the framework for Semantic IS Standards is evaluated against the combined set of criteria as described in the "Design Objectives" section.

- Usefulness: From the three use cases identified for the framework (see section "Design Objecives"), two could be tested in case studies. Whereas Case A is about selecting Semantic IS Standards, Case B aimed at evaluating Semantic IS Standards. In both cases, the framework was deemed useful by the project stakeholders with regard to supporting the project's purpose. In Case A the framework helped identify concepts which had not been considered before, but were then considered important to be addressed. In Case B, the framework was used with a special focus on business object related standards. The general applicability for evaluation purposes was confirmed by the stakeholders in Case B. Moreover, one Siemens participant pointed out that for corporate-wide recommendation of the top-ranked standards, further analysis was necessary. In particular, the demand for reference implementation in software tools was articulated-what supports the inclusion of the sub-category "Implementation" in the framework. The third use case, namely the influencing of existing standards, was not tested and should be part of future research.

- Appropriateness and systematic structure: The hierarchical structure and the grouping of concepts into categories were not issues of discussion in the case

\footnotetext{
9 See http://www.acord.org.

${ }^{10}$ Common Information Model, see http://www.dmtf.org/standards/cim.

11 See http://www.hl7.org/.

12 See http://www.tmforum.org/InformationFramework/1684/home.html.

13 Core Components Technical Specification, see http://www.unece.org/cefact/codesfortrade/unccl/ CCL_index.htm.
} 
studies. Since the framework was applied successfully in both cases, the silence on this point might be interpreted as a high parameter value.

- Clarity: The validation in the practitioners' community (both through expert interviews and case studies) has shown that the description of concepts is of high relevance for the framework to be considered "clear". As standardization in general, and Semantic IS Standards in particular, are considered an "abstract" topic in the practitioners' community, a clear definition of the meaning of concepts was necessary.

- Completeness: The case studies have shown that the framework is considered complete with regard to the scope it was designed for. However, for evaluation purposes the concepts included must be accompanied by scales (which is not included in the current version of the framework). In particular Case B has delivered evidence that the identification and documentation of a reference scales would be a reasonable area of future research.

\section{Discussion}

The discussion of the findings comprises both the design of the framework itself and its application in the two case studies. The characteristics framework for Semantic IS Standardization is based on the analysis of both the scientific and practical stateof-the-art. While theory supports the inclusion of individual concepts-as shown in Sect. 4.3-the framework in return also allows for some theoretical conclusions.

One example is given by sub-category 3.2 ("Organization") which includes six individual concepts. These concepts address aspects such as "Governance" and "Rights management", i.e. the interplay of different stakeholders in the standards development and maintenance process. The apparent relevance of this topic indicates a demand to avoid "power games" as described by Nickerson and zur Muehlen (2006) and to establish clear rights and responsibilities.

A second example refers to the concept of "openness". The framework design confirms the understanding of openness being a multidimensional concept which cannot be unambiguously valued (Krechmer 2009). Further research, though, should study openness in the light of sponsored and unsponsored standards (Stango 2004) and also within standardization "ecosystems" (Nickerson and zur Muehlen 2006).

A third example is given by the concept 1.2.3 ("Costs and Benefits") which was used in Case A, but was not applied in Case B. The fact that a private business rated the concept apparently less important than a public authority corresponds with findings by Weitzel et al. (2006). They found that costs of standards adoption are relatively easy to quantify while the benefits might not be quantifiable at all. Consequently, the concept might be of limited value for standards end users.

Furthermore, Case A shows that the characteristics framework is considered a useful instrument for policy makers in their ambition to support and guide the standard development process. This guidance might help to reduce the risk of "power games" and "standard wars" as described in literature (Nickerson and zur Muehlen 2006; Stango 2004).

Besides demonstrating the applicability of the framework as a whole and of individual concepts the cases allow for further interpretation. Case Study B revealed 
the need for reference implementations and software support in the practitioners' community. Reference implementations similar to Amaya (Quint 2010) do not exist in the area of Semantic IS Standards. This might be a promising field for future research. And despite the influence of vendors on standards adoption (Chen and Forman 2006) there is a high demand for Semantic IS Standards being supported by software solutions. In Case B, for example, "tool support" was rated a top-priority during the evaluation process because Siemens Corporate Technology wanted to know whether the Semantic IS Standards are supported by SAP's software WARP $10^{14}$ amongst others. In general, the importance of software support for Semantic IS Standards confirms the path dependency theory according to which standards adoption at a certain point of time depends on previous adoption (Economides 1996).

Moreover, the expressiveness of a Semantic IS Standard was rated very important (see Fig. 3). As of today, this topic is hardly addressed by literature. One of the few available contributions analyzes the quality of Semantic IS Standards and address the expressiveness implicitly, namely as a quality dimension of a standard's effectiveness (Folmer et al. 2011, p. 100).

\section{Conclusions and outlook}

This paper reports on the design of a characteristics framework for Semantic IS Standards. The framework is grounded in both theory and practice and its applicability was checked in two case studies.

The framework contributes to the scientific body of knowledge in the field as it adds to a better understanding of the characteristics of Semantic IS Standards. Future research on the analysis and design of Semantic IS Standards can take up on the results. Apart from that, this paper identifies some theoretical implications (see Sect. 7). An example is the importance of software support for practitioners' what - to a certain extent - stands in contrast to the risk of lock-in effects and increasing switching costs (Chen and Forman 2006). And the comprehensive coverage of organizational concepts (see subcategory 3.2) indicates a demand for future research in this area.

Apart from that, the framework seems to be useful for practitioners. In the case studies it supports a regulator in the process of public guidance with regard to the use and development of standards. And furthermore, it supports a private company in the process of evaluation of standards for internal use. Further development might help increasing its usefulness. An example would be a method which outlines process steps for the application of the framework in the three use cases introduced above. The design of such a method would help to improve and further develop the framework itself while at the same time supporting its more wide-spread application.

Open Access This article is distributed under the terms of the Creative Commons Attribution Noncommercial License which permits any noncommercial use, distribution, and reproduction in any medium, provided the original author(s) and source are credited.

\footnotetext{
14 WARP 10 is a software prototype developed by SAP Research. The software aims at facilitating the reuse of schemas of XML-based standards and their mappings (Stuhec 2007). The Siemens Corporate Technology participants in Case Study B were also involved in information exchanges with regard to WARP 10 between Siemens and SAP.
} 


\section{Appendix 1: Existing frameworks for Semantic IS Standards}

\begin{tabular}{|c|c|c|c|c|}
\hline $\begin{array}{l}\text { Approach/ } \\
\text { framework }\end{array}$ & $\begin{array}{l}\text { A. Evaluation } \\
\text { framework } \\
\text { (Mykkanen and } \\
\text { Tuomainen 2008) }\end{array}$ & $\begin{array}{l}\text { B. Reference model } \\
\text { analysis grid } \\
\text { (RMAG) (Pawlowski } \\
\text { and Kozlov 2010) }\end{array}$ & $\begin{array}{l}\text { C. Comparative } \\
\text { analysis (Nelson et al. } \\
\text { 2005) }\end{array}$ & $\begin{array}{l}\text { D. Evaluation } \\
\text { taxonomy } \\
\text { (Lampathaki et al. } \\
\text { 2009) }\end{array}$ \\
\hline Purpose & $\begin{array}{l}\text { Evaluation of a } \\
\text { specific (or } \\
\text { relative } \\
\text { comparison) } \\
\text { interoperability } \\
\text { standard(s) }\end{array}$ & $\begin{array}{l}\text { Assessing, testing } \\
\text { and validation of } \\
\text { standards for } \\
\text { achieving } \\
\text { interoperability in } \\
\text { the education } \\
\text { domain }\end{array}$ & $\begin{array}{l}\text { Analysis and } \\
\text { comparison of } \\
\text { multiple vertical } \\
\text { standards }\end{array}$ & $\begin{array}{l}\text { To classify business } \\
\text { transaction } \\
\text { standards based on } \\
\text { taxonomy related } \\
\text { information of a } \\
\text { standard }\end{array}$ \\
\hline $\begin{array}{l}\text { Categories } \\
\text { and } \\
\text { concepts } \\
\text { included }\end{array}$ & $\begin{array}{l}\text { A.1. Overview } \\
\text { A.2. Information } \\
\text { and semantics } \\
\text { A.3. } \\
\text { Functionality } \\
\text { and interactions } \\
\text { A.4. Application } \\
\text { infrastructure } \\
\text { A.5. Technical } \\
\text { aspects } \\
\text { A.6. Flexibility, } \\
\text { accuracy, } \\
\text { extensibility } \\
\text { A.7. Maturity, } \\
\text { usage, official } \\
\text { status } \\
\text { A.8. System life- } \\
\text { cycle } \\
\text { A.9. Domain- } \\
\text { specific features }\end{array}$ & $\begin{array}{l}\text { B.1. General data } \\
\text { B.2. Objectives } \\
\text { B.3. Domain } \\
\text { B.4. Classification } \\
\text { B.5. Methodology } \\
\text { B.6. Evaluation } \\
\text { B.7. Processes } \\
\text { B.8. Levels } \\
\text { B.9. Usage and } \\
\text { validation } \\
\text { B.10. Documentation } \\
\text { B.11. In-depth } \\
\text { analysis: } \\
\text { a. Practical } \\
\text { interoperability and } \\
\text { credibility } \\
\text { b. Semantic } \\
\text { interoperability } \\
\text { c. Integration: } \\
\text { communication } \\
\text { d. Bindings and } \\
\text { conformance } \\
\text { e. Integrity } \\
\text { B.12. Quality } \\
\text { attributes: } \\
\text { a. Seamlessness } \\
\text { b. Adaptation } \\
\text { c. Document } \\
\text { guidance } \\
\text { d. Compatibility } \\
\text { e. Extensibility, } \\
\text { adaptation }\end{array}$ & $\begin{array}{l}\text { C.1. Context } \\
\text { (industrial group, } \\
\text { URL, profit } \\
\text { orientation/ } \\
\text { partnerships, } \\
\text { membership fee } \\
\text { structure, industry } \\
\text { participation, } \\
\text { decision making, } \\
\text { standards } \\
\text { availability, } \\
\text { members, year } \\
\text { incepted } \\
\text { C.2. Choreograph and } \\
\text { modularity: } \\
\text { a. High-level } \\
\text { processes } \\
\text { b. Specification sets } \\
\text { C.3. Prioritize and } \\
\text { schedule: } \\
\text { a. Decision-making } \\
\text { b. Update } \\
\text { C.4. Standardize and } \\
\text { document } \\
\text { a. Typical } \\
\text { specification sets } \\
\text { b. Sub-committee } \\
\text { structure } \\
\text { C.5. Reviews and } \\
\text { tests } \\
\text { C.6. Implement and } \\
\text { deploy } \\
\text { C.7. Compliance and } \\
\text { certification }\end{array}$ & $\begin{array}{l}\text { D.1. Scope } \\
\text { D.2. Completeness } \\
\text { D.3. Compatibility } \\
\text { (with other } \\
\text { standards) } \\
\text { D.4. Openness } \\
\text { D.5. Customization } \\
\text { capabilities } \\
\text { (modularity, } \\
\text { expandability, } \\
\text { composability) } \\
\text { D.6. Maturity } \\
\text { D.7. Standard } \\
\text { support } \\
\text { D.8. Ease of use and } \\
\text { of implementation } \\
\text { D.9. Modeling of } \\
\text { messages } \\
\text { D.10. Integrated } \\
\text { management of } \\
\text { enterprise and data } \\
\text { models } \\
\text { D.11. Configuration } \\
\text { Management } \\
\text { (versioning, } \\
\text { backwards } \\
\text { compatibility) } \\
\text { D.12. Additional } \\
\text { features (support } \\
\text { for rules modeling, } \\
\text { workflow } \\
\text { capabilities, } \\
\text { incorporated into } \\
\text { the documents) }\end{array}$ \\
\hline
\end{tabular}




\section{Appendix 2: Example of a Semantic IS Standard classification in Case A}

\section{cfiXML}

General characteristics

1. Name of the standard

2. Functional and organizational domain

3. Website
cfiXML (capital facilities industry XML)

Worldwide standard for data exchange for the capital facilities industry: building and maintenance of large utility buildings (offices, shops, hospitals), industry plants and (technical) facilities

http://www.cfixml.org/

The standard supports and aligns the information exchange between the stakeholders in the capital facilities industry, thereby considerably saving costs in the long run, according to NIST research

Current use ('usability' in terms of Dutch "Comply or Explain" policy)

4. Usage on national/European/international level International, primarily US

5. Start date

6. Important stakeholders

7. Number of participants
2004; First public release

The so-called sponsors; consortiums (FIATECH) and associations (DIPPR) that are representing owners, engineering procurement and construction contractors, technology suppliers, equipment suppliers, universities and research organizations

Broad application of the standard in the United States, including several international companies (among them Royal Shell)

The standard is particularly used by American companies. Moreover, some sectors use it more intensively than others, for example the oil and gas industry

Potential ('potential' in terms of Dutch “Comply or Explain” policy)

\section{Level of adoption}

9. Contribution to economic and social goals

10. Contribution to reducing the administrative burden or to improved inspection
Adoption is limited to the US and to some internationally operating companies

The standard contributes to economic goals by lowering costs within the value chain

This is an industry standard with hardly any relation to the government. It does reduce the administrative burden, but on a B2B level rather than on a $\mathrm{B} 2 \mathrm{G}$ level

The standard has economic potential for the Netherlands and might result in a more competitive building and maintenance sector by reducing the administrative work

Development and maintenance ('openness' in terms of Dutch "Comply or Explain” policy)

11. Profit/non-profit orientation of organization

12. Finance model

13. Participation model

14. Decision model/governance
Non-profit

Payments of both sponsors and participating software companies

Everybody can participate

Not known (probably sponsors) 
Appendix 2 continued

Development and maintenance ('openness' in terms of Dutch “Comply or Explain” policy)

15. Availability

Open-source model is used, including minimal support. Information is freely available

Although the governance structure is not known, the standard builds on volunteers for its development, and the sponsors seem to heavily influence and direct the standard

Conclusions:

Usage of the standard by the Dutch government might have a flywheel effect for usage within the Dutch building industry. The standard brings in a solution to B2B interoperability problems related to complex projects, involving different stakeholders, including designers and providers of equipment and maintenance. For the big players in the utility construction field (including the government) the potential savings are huge. On the other hand, the potential regarding B2G, and in particular specific government tasks, seems limited

Further exploration involving the different stakeholders is recommended, especially focusing on the benefits of this standard for the stakeholders

\section{Appendix 3: Research process in case study A}

Case Study A was conducted at the Dutch Ministry of Economic Affairs between December 2010 and February 2011. The case study was of participatory nature (Baskerville 1997) and involved two researchers. The researchers had an active role in the case and closely collaborated with the principal at the ministry. However, the researchers did not influence any decision towards individual standards, but instead provided methodological support and analyzed the existing state-of-the-art. Case Study A aimed at validating the design of the characteristics framework as well as demonstrating its applicability.

The role of the main contact at the ministry was a senior policy maker. The collaboration was very close with frequent exchange of information on a weekly basis. In the course of the collaboration multiple forms of communication and data gathering were used-including on-site meetings, e-mail and several telephone conversations. On site sessions were conducted on January 18 and 26, 2011, for example. However, the majority of communication took place via telephone and e-mail due to the geographical distance between the researchers and the ministry.

\section{Appendix 4: Interview and workshop schedule in Case B}

\begin{tabular}{llll}
\hline No & Date & Meeting type & Siemens participants \\
\hline 1 & $\begin{array}{c}\text { July 15, 2010, } \\
1 \mathrm{~h}\end{array}$ & $\begin{array}{c}\text { Conference call, kick-off } \\
\text { preparation }\end{array}$ & Consultant Siemens Corporate Technology \\
2 & $\begin{array}{c}\text { July 27, 2010, } \\
\text { Workshop, kick-off (Munich, } \\
\text { Germany) }\end{array}$ & $\begin{array}{l}\text { Consultant Siemens Corporate Technology } \\
\text { Senior consultant Siemens Corporate } \\
\text { Technology }\end{array}$ \\
& & $\begin{array}{l}\text { Subject matter expert Siemens corporate } \\
\text { information technology }\end{array}$ \\
& & \\
\end{tabular}


Appendix 4 continued

\begin{tabular}{|c|c|c|c|}
\hline No & Date & Meeting type & Siemens participants \\
\hline 3 & $\begin{array}{l}\text { August } 5 \text {, } \\
2010,1 \mathrm{~h}\end{array}$ & Conference call & Consultant Siemens Corporate Technology \\
\hline 4 & $\begin{array}{l}\text { August } 26 \text {, } \\
2010,3 \mathrm{~h}\end{array}$ & $\begin{array}{l}\text { Conference call, review of long } \\
\text { list }\end{array}$ & $\begin{array}{l}\text { Consultant Siemens Corporate Technology } \\
\text { Senior consultant Siemens Corporate } \\
\text { Technology } \\
\text { Subject matter expert Siemens corporate } \\
\text { information technology }\end{array}$ \\
\hline 5 & $\begin{array}{l}\text { September } \\
21,2010 \\
1 \mathrm{~h}\end{array}$ & $\begin{array}{l}\text { Conference calls, review of short } \\
\text { list and adoption of framework }\end{array}$ & Consultant Siemens Corporate Technology \\
\hline 6 & $\begin{array}{l}\text { October } 1, \\
2010,2 \mathrm{~h}\end{array}$ & & \\
\hline 7 & $\begin{array}{l}\text { October } 14, \\
2010,1 \mathrm{~h}\end{array}$ & & \\
\hline 8 & $\begin{array}{l}\text { November } \\
18,2010 \\
2 \mathrm{~h}\end{array}$ & $\begin{array}{l}\text { Conference call, review of } \\
\text { evaluation }\end{array}$ & Consultant Siemens Corporate Technology \\
\hline 9 & $\begin{array}{l}\text { April 5, } \\
2011,2 \mathrm{~h}\end{array}$ & $\begin{array}{l}\text { Workshop, final result } \\
\text { presentation (Munich, } \\
\text { Germany) }\end{array}$ & $\begin{array}{l}\text { Consultant Siemens Corporate Technology } \\
\text { Senior consultant Siemens Corporate } \\
\text { Technology } \\
\text { Subject matter expert Siemens corporate } \\
\text { information technology }\end{array}$ \\
\hline
\end{tabular}

\section{Appendix 5: Example of a Semantic IS Standard evaluation in Case B}

\section{ACORD framework}

\begin{tabular}{ll}
\hline Evaluation criteria & Value \\
\hline Version & Dictionary-published, 2008 \\
& Capability model-published, 2007; ver. 2.0 published Nov, 2009 \\
& Information model-initial release, August, 2009, update 2.0 in 2001 \\
& Data model 1.x-incremental releases in 2010 \\
& Component model-start in 2010 \\
& AIM harmonization with IBM BOM-2010 \\
& The ACORD Framework represents a single streamlined business \\
& model for standards creation that is flexible enough to cross lines \\
Description & of business and geographic borders \\
& - \\
Registered standard & - \\
Standardization organization & Insurance industry \\
Industry & Clinical data, person data, product data \\
Scope & ACORD (association for cooperative operations research and \\
Developer & development)
\end{tabular}


Appendix 5 continued

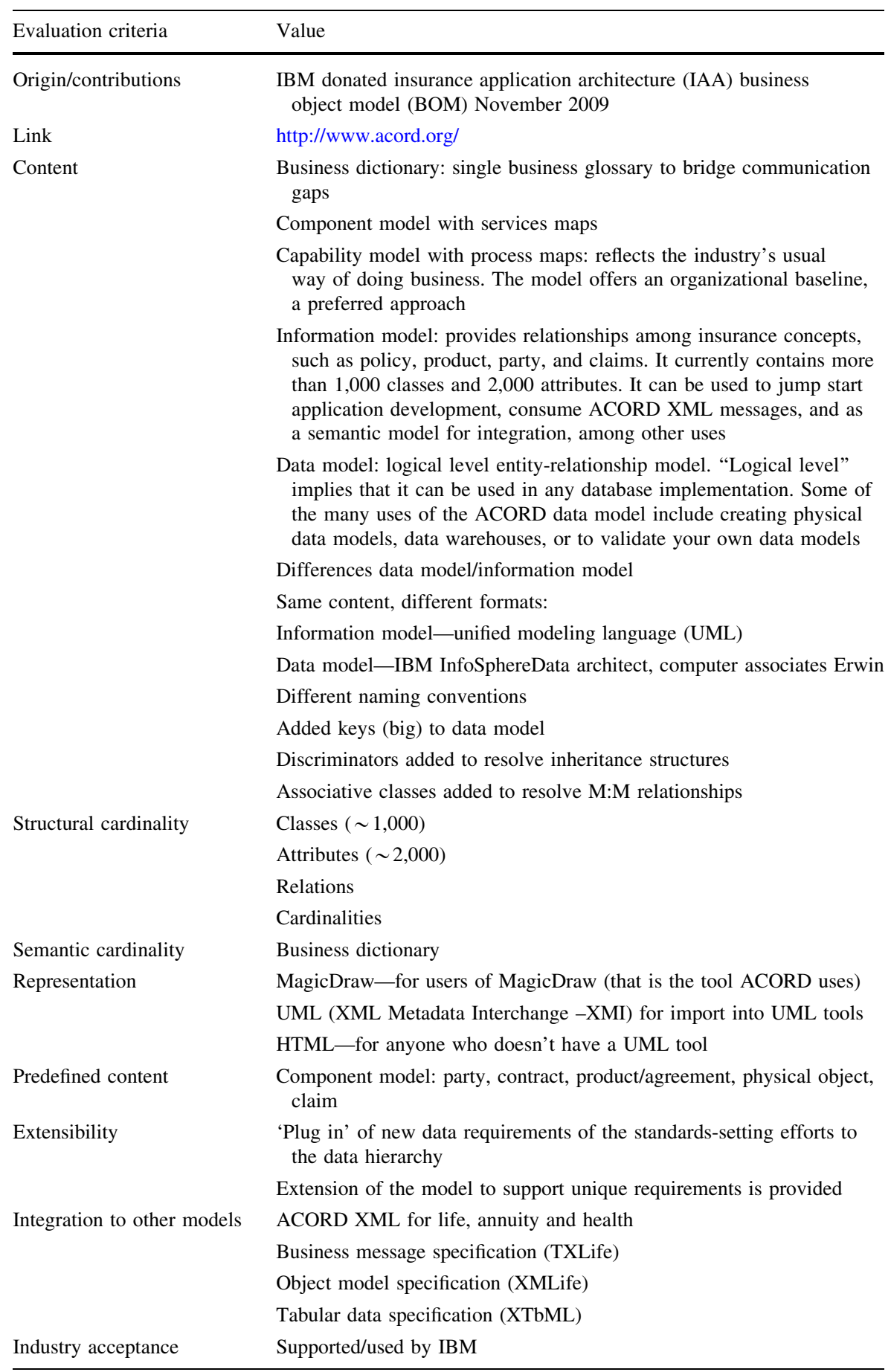


Appendix 5 continued

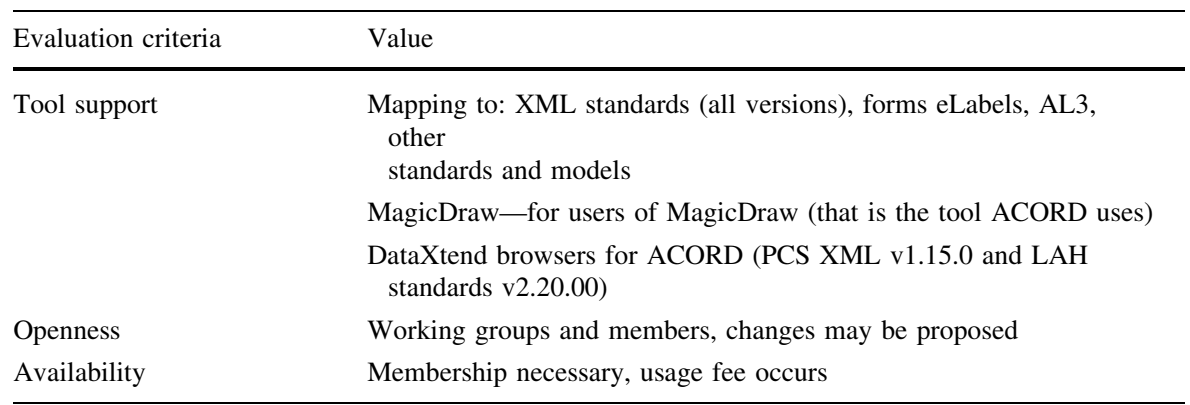

\section{References}

Alt R, Fleisch E (2000) Business networking systems: characteristics and lessons learned. Int J Electron Commer 5(2):7-27

Backhouse J, Hsu CW, Silva L (2006) Circuits of power in creating de jure standards: shaping an international information security standard. MIS Q 30(SI):413-438

Baskerville RL (1997) Distinguishing action research from participative case studies. J Sys Inf Technol 1(1):24-43. doi:10.1108/13287269780000733

Becker J, Rosemann M, Schütte R (1995) Grundsätze ordnungsmäßiger Modellierung (German: guidelines for orderly modeling). Wirtschaftsinformatik 37(5):435-445

Benbasat I, Zmud R (1999) Empirical research in information systems: the practice of relevance. MIS Q 23(1):3-16

Boh WF, Soh C, Yeo S (2007) Standards development and diffusion: A case study of RosettaNet. Commun ACM 50(12):57-62

Brackett MH (1994) Data sharing using a common data architecture. Wiley, New York

Chang C, Jarvenpaa S (2005) Pace of information systems standards development and implementation: the case of XBRL. Electron Mark 15(4):365-377. doi:10.1080/10196780500303029

Chen M (2003) Factors affecting the adoption and diffusion of XML and Web services standards for E-business systems. Int J Human Comput Stud 58(3):259-279. doi:10.1016/S1071-5819(02) 00140-4

Chen PY, Forman C (2006) Can vendors influence switching costs and compatibility in an environment with open standards? MIS Q 30(SI):541-562

Chikofsky EJ, Cross JHI (1990) Reverse engineering and design recovery: a taxonomy. IEEE Soft 7(1):13-17. doi:10.1109/52.43044

David PA, Greenstein S (1990) The economics of compatibility standards: an introduction to recent research. Econ Innov New Technol 1(1-2):3-41

De Leenheer P, Christiaens S, Meersman R (2010) Business semantics management: a case study for competency-centric HRM. Comput Ind 61(8):760-775. doi:10.1016/j.compind.2010.05.005

Economides N (1996) The economics of networks. Int J Ind Organ 14(6):673-699

Eisenhardt KM (1989) Building theories form case study research. Acad Manag Rev 14(4):532-550

European Commission (2009) Modernising ICT standardisation in the EU-the way forward. European Commission, Brussels

Folmer E, Berends W, Oude Luttighuis P, Van Hillegersberg J (2010) Top IS research on quality of transaction standards, a structured literature review to identify a research gap. In: Paper presented at the 6th international conference on standardization and innovation in information technology, Tokyo, September 8-10, 2009

Folmer E, Oude Luttighuis P, van Hillegersberg J (2011) Do semantic standards lack quality? A survey among 34 semantic standards Electron Mark 21(2):99-111. doi:10.1007/s12525-011-0058-y 
Gregor S (2006) The nature of theory in information systems. MIS Q 30(3):611-642

Greiner U, Legner C, Lippe S, Wende K (2007) Business interoperability profiles: relating business interoperability issues to technical interoperability solutions. In: Paper presented at the proceedings of the 3rd international conference on interoperability for enterprise software and applications (IESA 2007), Funchal, March 21, 2007

Grindley P (1995) Standards, strategy, and policy: cases and stories. Oxford University Press, Oxford

Gruber T (1993) A translation approach to portable ontology specifications. Knowl Acquis 5(2):199-220

Harel D, Rumpe B (2004) Meaningful modeling: what's the semantics of "Semantics"? Computer 37(10):64-72. doi:10.1109/MC.2004.172

Hoberman S (2005) Data modelling made simple: a practical guide for business and IT professionals. Technics Publications, Bradley Beach

Hoberman S, Burbank D, Bradley C (2009) Data modeling for the business-a handbook for aligning the business with IT using high-level data models, 1st edn. Technics Publications, Bradley Beach

Hofreiter B, Huemer C, Kim J-H (2007) Choreography of ebXML business collaborations. Inf Syst e-Bus Manag 4(3):221-243. doi:10.1007/s10257-005-0016-3

Hørlück J (1996) Interorganisational systems: communication, cooperation, or governance? In: Holmqvist B, Andersen PB, Klein H, Posner R (eds) Signs of work: semiosis and information processing in organisations. de Gruyter, Berlin, pp 13-58

ISO/IEC (2004) Standardization and related activities—general vocabulary (ISO/IEC GUIDE 2:2004). ISO/IEC, Geneva

Jardine DA (1977) ANSI/SPARC DBMS model. Elsevier, Oxford

Kabak Y, Dogac A (2010) A survey and analysis of electronic business document standards. ACM Comput Surv 42(3):1-31. doi:10.1145/1670679.1670681

Kajan E, Stoimenov L (2005) Toward an ontology-driven architectural framework for B2B. Commun ACM 48(12):60-66. doi:10.1145/1101779.1101810

Kelly D, Feller J, Finnegan P (2006) Complex network-based information systems (CNIS) standards: toward an adoption model. In: Donnellan B, Larsen T, Levine L, DeGross J (eds) The transfer and diffusion of information technology for organizational resilience, vol 206. International federation for information processing (IFIP). Springer, Boston, pp 3-20

Krechmer K (2009) Open standards: a call for change. IEEE Commun Mag 47(5):88-94

Kroes N (2010) How to get more interoperability in Europe (address at open forum Europe 2010 summit: openness at the heart of the EU digital agenda). European Union, Brussels

Lampathaki F, Mouzakitis S, Gionis G, Charalabidis Y, Askounis D (2009) Business to business interoperability: a current review of XML data integration standards. Comput Stand Interfaces 31(6):1045-1055. doi:10.1016/j.csi.2008.12.006

Lee TY (1999) Information modeling: from design to implementation. In: Proceedings of the 2nd world manufacturing congress. Durham, pp 315-321

Legner C, Lebreton B (2007) Business interoperability research: present achievements and upcoming challenges (preface to the focus theme section: "Business Interoperability"). Electron Mark 17(3):176-186. doi:10.1080/10196780701503054

Legner C, Wende K (2006) Towards an excellence framework for business interoperability. In: Paper presented at the 19th bled eConference (eValues), Bled, June 5-7, 2006

Markus ML, Steinfield CW, Wigand RT, Minton G (2006) Industry-wide information systems standardization as collective action: the case of the U.S. residential mortgage industry. MIS Q 30(SI):439-465

Mendoza RA, Ravichandran T (2007) Organizational assimilation of vertical standards: an integrative model. In: Paper presented at the proceedings of the 40th annual Hawaii international conference on system sciences (HICSS-40), Waikoloa, HI, January 3-6, 2007

Meuser M, Nagel U (1994) Expertenwissen und experteninterview (German: expert knowledge and expert interview). In: Hitzler R, Honer A, Maeder C (eds) Expertenwissen. Die institutionelle Kompetenz zur Konstruktion von Wirklichkeit (German: expert knowledge: institutional competence for reality construction). Westdeutscher, Opladen, pp 180-192

Müller JE (1982) Face-to-face interaction and its notation. In: Hess-Lüttich EWB (ed) Multimedial communication, vol 1 (semiotic problems of its notation). Narr, Tübingen, pp 17-29

Mykkanen JA, Tuomainen MP (2008) An evaluation and selection framework for interoperability standards. Inf Softw Technol 50(3):176-197. doi:10.1016/j.infsof.2006.12.001

Nelson ML, Shaw MJ, Qualls W (2005) Interorganizational system standards development in vertical industries. Electron Mark 15(4):378-392. doi:10.1080/10196780500303045 
Nickerson JV, zur Muehlen M (2006) The ecology of standards processes: insights from internet standard making. MIS Q 30(SI):467-488

NOiV (2011) Management and development model for open standards (BOMOS) Version 2. Part 1: the fundamentals. Nederland Open in Verbinding, The Hague

OMG ORMS (2001) Model driven architecture (MDA). OMG object and reference model AB subcommittee, Needham, MA

Österle H (1995) Business engineering: Prozess- und Systementwicklung (German: business engineering: process and system development), vol 1, vol 1, 2nd edn. Springer, Berlin

Österle H (1996) Business engineering: transition to the networked enterprise. Electron Mark 6(2):14-16

Österle H, Blessing D (2003) Business engineering model. In: Österle H, Winter R (eds) Business engineering, 2nd edn. Springer, Berlin, pp 65-85

Österle H, Fleisch E, Alt R (1999) Business networking. Shaping enterprise relationships on the internet. Springer, Berlin

Pawlowski JM, Kozlov D (2010) Analysis and validation of learning technology models, standards and specifications: the reference model analysis grid (RMAG). Int J IT Stand Stand Res 8(2):1-19. doi: 10.4018/jitsr.2010070101

Quint V (2010) Amaya home page. INRIA, W3C. http://www.w3.org/Amaya/. Accessed September 1, 2011

Rukanova B (2005) Business transactions and standards: towards a system of concepts and a method for early problem identification in standard implementation projects. Febo Druk, Enschede

Scheer A-W (1992) Architecture of integrated information systems-foundations of enterprise modelling. Springer, Berlin

Stango V (2004) The economics of standards wars. Rev Netw Econ 3(1):1-19

Steinfield CW, Wigand RT, Markus ML, Minton G (2007) Promoting e-business through vertical IS standards: lessons from the US home mortgage industry. In: Greenstein S, Stango V (eds) Standards and public policy. Cambridge University Press, Cambridge, pp 160-207

Stuhec G (2005) How to solve the business standards dilemma. SAP AG. https://www.sdn.sap.com/irj/ servlet/prt/portal/prtroot/docs/library/uuid/a6c5dce6-0701-0010-45b9-f6ca8c0c6474. Accessed April 30,2007

Stuhec G (2007) Using CCTS modeler warp 10 to customize business information interfaces. SAP. http:// www.sdn.sap.com/irj/scn/go/portal/prtroot/docs/library/uuid/70d6c441-507e-2a10-7994-88f6f769 d6e8?QuickLink=index\&overridelayout=true. Accessed September 7, 2011

Tanenbaum AS (1989) Computer networks. Prentice-Hall, Englewood Cliffs

Thomas JW, Probets S, Dawson R, King T (2008) A case study of the adoption and implementation of STEP. In: Egyedi TM, Blind K (eds) The dynamics of standards. Edward Elgar, Cheltenham, pp 117-134

Uschold M, Gruninger M (2004) Ontologies and semantics for seamless connectivity. SIGMOD Rec 33(4):58-64

Van Wessel RM (2008) Realizing business benefits from company IT standardization; case study research into the organizational value of IT standards, towards a company IT standardization management framework. Tilburg University, Tilburg

Vogel T (2010) Serviceorientiertes business networking-Referenzarchitektur und Gestaltungsprinzipien (German: service-oriented business networking-reference architecture and design principles). Dissertation, University of St. Gallen, St. Gallen

Weitzel T, Beimborn D, König W (2006) A unified economic model of standard diffusion: the impact of standardization cost, network effects, and network topology. MIS Q 30(SI):489-514

Yin RK (2002) Case study research: design and methods, 3rd edn. Sage Publications, Thousand Oaks

Zhao K, Xia M, Shaw MJ (2005) Vertical e-business standards and standards developing organizations: a conceptual framework. Electron Mark 15(4):289-300

Zhao K, Xia M, Shaw MJ (2007) An integrated model of consortium-based e-business standardization: collaborative development and adoption with network externalities. J Manag Inf Syst 23(4):247-271 